\title{
Repatriation as a Solution of Afghan Refugee Crisis: A Critical Overview
}

\author{
Sumaya Khan Auntu and Afia Tasnim Promee
}

\begin{abstract}
Since 1979, the Afghan refugee crisis is the second largest refugee crisis in the world which is termed as "Protracted Refugee Situation". Since then, the neighboring countries, the Islamic Republic of Iran and the Islamic Republic of Pakistan have provided support in terms of sheltering the refugees and conducting the measures of durable solutions. Last year, it marked the fourth decade of the crisis, and there is still no permanent solution. Different measures have been taken, among them, Solutions Strategy for Afghan Refugees (SSAR) is the most significant one. In this paper, a qualitative approach involving secondary data sources critically evaluates the effects of repatriation as a solution to the Afghan refugee crisis. This paper had tried to illustrate significant initiatives taken by UNHCR and the governments of Afghanistan, Pakistan, and Iran along with the international community. In conclusion, some policies are recommended to make voluntary repatriation more effective.
\end{abstract}

Index Terms - Crisis, Protracted, Refugee, Solution, Voluntary Repatriation, UNHCR.

\section{INTRODUCTION}

Repatriation is considered as one of the viable solutions to the 'refugee problems. It can be voluntary or forcibly. While the refugees and the host countries face various kinds of problems because of refugee crisis, sending refugees back to their own country, be it voluntarily or be it forcibly, is done to solve the issues. When the refugees once return to their country of origin either voluntarily or forcibly, their safety and security issues are less likely to be observed. It is a controversial phenomenon of the cooperation between the host country and country of origin that has already created global tension. There are no differences in the case of the Afghan refugees as well. According to the UNHCR report, $57 \%$ of refugees of the world belong to these three countries: Syria, Afghanistan, and South Sudan [1]. Afghanistan ranked in the second position among them. About $80 \%$ of the Afghan refugees are sheltered by their neighboring countries, the Islamic Republic of Iran and the Islamic Republic of Pakistan. The Joint IOM-UNHCR Summary Report on Returns to Afghanistan (2017) stated that in 2016 there was a spike in returns to Afghanistan, with more than 370,000 returnees from Pakistan and Iran. Again surprisingly, this number had reduced to 58,800 in 2017 and 12,785 on September 2018 [2]. These

Published on December 17, 2020

Sumaya Khan Auntu, Department of International Relations, Bangladesh University of Professionals, Bangladesh.

(corresponding e-mail: sumaya.bupir17@gmail.com)

Afia Tasnim Promee, Department of International Relations, Bangladesh University of Professionals, Bangladesh.

(e-mail: promee.tp@gmail.com) irregularities cause more global tension while Afghanistan is already amid crises. Some inconsistencies in the repatriation process are mainly responsible for this.

In this paper, these inconsistencies will be critically analyzed and the initiatives by UNHCR, the legal guardian of the global refugee regime and the international community will be discussed through a qualitative approach and case study method using data from secondary sources.

\section{OBJECTIVES}

The purpose of the study is to evaluate the success and failure of the voluntary repatriation Afghan refugee crisis. The research will further denote the reasons behind their unwillingness of Afghan Refugees for repatriation.

There is a lack of literature to contrast the pre and post conditions of Afghan refugees. Many pieces of research highlight the host country and the reasons behind the host country to force them to repatriate. This study will focus on filling these gaps. It will recommend some policies to make repatriation more effective in resolving the world's secondlargest protracted refugee crisis.

Repatriation is considered as an effective solution to the refugee crisis by maximum scholars. However, there are several negative consequences generated from the repatriation process witnessed in the Afghan Refugee Crisis. The intrastate conflict situation and multiple trials of the balance of power have made the world concerned to resolve this Afghanistan refugee crisis where the evaluation of the repatriation process of how it can resolve this Afghan refugee crisis is concerning. This paper will help to identify the pre and post-repatriation process so that repatriation as a solution of the Afghan refugee crisis proceeds towards rectification and will give a better reflection in the future.

\section{HYPOTHESIS}

In this study, the variables include the Afghanistan government, UNHCR, the governments of host countries (Pakistan and Iran), Afghan refugees and the repatriation process. Here for this study, the governments of host countries and Afghanistan are independent variables; UNHCR is also an independent variable here; the Afghan refugees and their repatriation process are dependent variables.

Afghan refugees and their repatriation process are dependent because they depend upon the decisions of host governments, the government of Afghanistan and the UNHCR. They cannot work or act independently because if they do so, without the decision or permission of the governments, they might be recognized as illegal. 
For this study the primary hypothesis is- the repatriation of Afghan refugees depends upon the host governments and the Afghan government. While decisions of these governments make the refugees suffer, disobeying their orders might cause them more trouble like identifying as illegal.

\section{RESEARCH METHODOLOGY}

According to W. Lawrence Neuman, applied research refers to "research designed to offer practical solutions to a concrete problem or address the immediate and specific needs of clinicians or practitioners" [3]. It can be considered as a social impact assessment, as according to Neuman, the probable consequences for various areas of social life because of any new change introduced to a community are documented in a social impact assessment. This study follows an empirical research design, which refers to a research approach that makes use of evidence-based data [4]. As per the empirical research design, this study has a set of research questions that guides the investigation; the research variables are clearly defined, and the research process is described in detail.

For carrying out this research the qualitative methodology has been used. It can be considered as applied, descriptive research. Content analysis of secondary literature and desk research is carried out to evaluate relevant information and statistics from available sources.

All the information interpreted in this paper is collected from secondary data sources. Secondary information is collected from websites, books, different academic journals, national and international journals, articles, magazines, etc. In this research, the author had followed the case study method to evaluate how repatriation is performing as a solution to the protracted Afghan refugee crisis and to determine the pre and post consequences.

The data collection technique used in this study is document analysis, which refers to analysis based on existing sources or papers. Existing sources include government reports, journal articles, personal documents, articles in newspapers, and books. It also includes virtual documents (e.g., websites). The interpretation of data represents through analyzing the comprehensive and analytical reasoning to determine the theories and ideas and to provide a framework of solution.

\section{DISCUSSION AND FINDINGS}

UNHCR asserted in their report 2018-19 that between March 2002 and September 2018 over 5.2 million Afghan refugees repatriated with UNHCR assistance through the world's largest voluntary repatriation program in history. These huge amounts of Afghan refugee repatriation along with the continued displacement to urban areas had affected the absorption capacity of Afghanistan. It was occurring due to the additional pressure on community services and regular social infrastructure in Afghanistan [1].

Afghanistan Multi-year Protection and Solutions Strategy (2019-2021) enlighten the world that according to the third meeting of the regional Quadripartite Steering Committee on 18 and 19 September 2013, near around 5.7 million Afghan refugee's repatriation was the world's largest repatriation operation. Afterward, the sudden declination of the Afghan refugees clearly indicates the unwillingness of voluntary repatriation by the Afghan refugees. Lack of shelter, job opportunities, educational and health facilities, fragile security situation due to armed conflicts between Government, pro-Government and Anti Government forces, new and protracted internal displacement due to the ongoing conflict and drought will continue to affect their lives. Even in cases of repatriation or resettlement, they face various types of tension between the returnees and the locals regarding property and land ownership. They do not get any assistance initially to meet their urgent needs after return or resettlement which makes their survival tougher [5].

According to the Solutions Strategy for Afghan Refugees, Enhancing Resilience and Co-Existence through Greater responsibility-sharing (2018) by UNHCR, this paper discusses the protracted refugee situation that has been going on in Afghanistan since 1979 due to the Afghan War and the US War in Afghanistan (2001) [1]. Features of Solutions Strategy for Afghan Refugees (SSAR) which is a measure taken by the combined effort of the Governments of Afghanistan, Iran, and Pakistan along with UNHCR. After that, it comes to the discussion on regional impacts and efforts provided by Pakistan and Iran as host countries. Different programs included in this big process have been illustrated such as the facilitation of voluntary repatriation measures undertaken by Iran and Pakistan.

The report published on Afghanistan Multi-year Protection and Solutions Strategy (2019-2021) by UNHCR, identified conflict and disasters with graphs and demographics as the reasons behind the migration and displacement of people [5]. The challenges and opportunities are discussed along with the successes in implementing the SSAR. In order to fulfill the demand for the protracted refugee situation, the decision of extending that process has been taken. The operational procedure of the multiyear protection, strategic policies, and solutions strategy has been discussed in brief. The five principles such as Protect, Respond, Include, Empower, and Solve has been elaborately discussed [5].

The Solutions Strategy for Afghan Refugees (SSAR) is the most significant and long-term process that has been initiated in 2011 to resolve this protracted refugee crisis in Afghanistan [1]. This paper evaluates the measures taken by SSAR along with its challenges and successes and illustrates the causes of expanding it as a multi-year protection and solution strategy.

At present, the situation stresses the demand for attaining political solutions and self-determined approaches in addressing the problem of Afghan refugees besides depending on foreign aid. The SSAR needs a supporting and cooperative platform that will monitor the changes from time to time to assure effectiveness [1].

UNHCR, representing the legal and normative framework of repatriation has projected a comparatively weak foundation in International Law enforcement. In response to that the refugees lost their faith in the international communities and shown unwillingness for repatriation. The legal and policy issues are holding back the flexible 
involvement of UNHCR in the repatriation management of the Afghan Refugee Crisis [6].

The Asia Pacific Refugee Rights Network (APRRN) is working for advancing and monitoring the rights of the refugees as negotiators, third party mediators along with capacity and resource strengthening and sharing. But the limitations of this organization are that it only reflects the overviews of the member states, as a result, fails to represent the rest.

UNHCR is the guardian of the wider global refugee regime. Article 14 of UDCR (1948) declared the freedom of someone to seek asylum in the host country from persecution. UNHCR supports and monitors the state's compliance in terms of norms and values based on the global refugee regime. The host country cannot force the refugees to repatriate because of their moral obligations; the international communities are bound to provide financial assistance to the host country as well.

Moreover, the international community should ensure that not only the neighboring countries take over the entire pressure of these increased number of refugees, rather responsibility-sharing initiatives should be addressed through the joint advocacy and resource mobilization efforts under the Joint Resource Mobilization Strategy (JRMS) [5].

\section{STUDY RESUlT}

Though in the present context, these sorts of ideological justification or moral obligations are almost disappeared, the host countries have started to project comparatively restrictive policies [1].

The political relations between Pakistan and Afghanistan have faced several security crises, Pakistan government decided to forcefully drive out the Afghan refugees. In the second half of 2016, 1.5 million registered Afghan refugees and 1 million undocumented Afghans represent the huge amounts of the largest unlawful forced repatriations of the Afghan refugees [7].

While talking with a female refugee in Pakistan, she had reported to Al Jazeera (2018) that she does not want to go back to her homeland Afghanistan under any conditions because of extreme levels of violence, and most often, they experience forced recruitment of their children as child soldiers [8]. Military forces recruit their children in military operations. Sometimes the Taliban Fighters kidnap the children and use them as anti-state elements like the suicide bombers, planting improvised explosive devices (LEDs), the combatants use them as a bodyguard in checkpoints, or utilize them in intelligent gathering in terrorist activities. For example, the UN report (2017) represented 84 cases of children kidnapping. Sometimes they receive threats from the Taliban Fighters, their male members of their family are killed or sometimes their families and houses are destroyed [9].

The World Health Organization Report (2017) showed that 24 health facilities of the repatriated Afghan Refugees were cut off while 164 were temporarily cut off due to insecurity and conflicts. Moreover, the way the Taliban are flagellating woman's rights in Afghanistan raises tension along with several attacks on the school premises in Afghanistan [10].
The Peace Agreement between the United States and the Taliban signed in early 2020 has created hope between all the Afghan refugees that this time, they may get back to their homelands again [11]. But this scenario is not common for all. There are some Afghan refugees who all have left their countries long ago. At present, though they are getting opportunities to come back to their homeland. But most of them are quite well-settled in the host countries. These individuals will not be willing to come back. Moreover, the returnees will face considerable challenges, including a lack of access to employment, land, education, identification cards, and health certificates, increasing levels of debt, child marriage, and trafficking, and threats of generalized violence. Sometimes returning to the country of origin after a long time may cause a secondary form of displacement, where their minimum livelihood support is absent.

\section{LIMITATIONS}

First, the paper was seen through the perspective of specific theories only but there might be other perspectives that have not been noted here, hence, the analysis is limited. Second, the paper uses secondary data from other scholars which could lead to a biased point of view towards one type of theory to explain the topic at hand. Third, the resource of secondary data was limited which ultimately keeps the information of this paper limited.

\section{CONCLUSION}

Afghan refugees experience a secondary form of displacement after returning to the country of origin. It is seen from the above analysis that significant successes have been achieved in the aspect of refugee repatriation for both of the external and internally displaced people. Some drawbacks are still existent which are making this situation lengthier to be solved. In response to the contemporary demands of the refugees and internally displaced people, the duration of the program has been extended. The effective performance of UNHCR may build trust in the mind of the refugees and motivate them for repatriation, but under no circumstances, the host country should send back the refugees if there is any probability of persecution in the future. The concerned authorities need to take the necessary steps to take care of this matter.

\section{RECOMMENDATIONS}

Erin D. Mooney, Deputy Director, Brookings Institution, delivered a speech highlighting some of the measures to support and strengthen the SSAR program in a workshop of UNDP titled "Lessons Learning from Experience for Afghanistan". They are as follows:

1) He stressed to avoid the creation of any further tension between the returnees and the locals. The returnees should be assisted through integration in broader community-based development schemes.

2) It is important to include the displaced women in the decision-making process as they are also the victims of this protracted refugee crisis. 
3) When refugees and displaced persons return, they experience several disputes over property and land ownership which may generate conflict and insecurity. A legal framework should be oriented to deal with these problems monitored by the government.

4) Sometimes mines are laid in the areas of return or resettlement which may cause a security crisis. So, before conducting a repatriation operation, the state government should check the land properly to avoid any sort of mishaps.

Along with the above-mentioned issues, in this paper, some more points are likely to be addressed as recommendations for future improvement. They are as follows.

1) The most important aspect to be taken care of is internal and external security. The conflict between the Government, Pro-Government and Anti Government forces, conflict among the local people, and repatriated refugees over limited resources and undocumented lands act as the negative catalyst that causes the retardation of the crisis resolution. So, if security problems are not addressed, and the required actions are not taken, then the solution will remain a far-fetched dream.

2) National Security forces inside and at the border will help to secure both the internal environment and sovereignty that is crucial to preserve peace.

3) The issues like unemployment, unregistered lands, and resources, etc. should be addressed, and measures should be taken to solve those as soon as possible.

4) Regional cooperation, International community promptness, and accountability are needed to ensure the restoration of human rights and justice in Afghanistan and solve the protracted refugee crisis durably.

5) In response to the COVID-19, due to limited resources and health facilities, Afghanistan along with its neighboring host countries like Pakistan and Iran tends to leave the refugees. This situation should be taken care of immediately.

\section{DECLARATION OF CONFLICT OF INTEREST}

The authors declared no potential conflicts of interest concerning the research, authorship and/or publication of this article.

\section{FUNDING}

The authors received no financial support for the research, authorship and/or publication of this article.

\section{ACKNOWLEDGMENT}

Guidelines from Ushree Barua, Lecturer of Department of International Relations, Bangladesh University of Professionals, are gratefully acknowledged.

\section{REFERENCES}

[1] "Solutions Strategy for Afghan Refugees", Enhancing Resilience And Co-Existence Through Greater Responsibility-Sharing 2018, presented at the UNHCR conference, Geneva, 2018.

[2] E.Browne.What Role have Joint Commissions Played in Facilitating Refugee Returns as Part of Peace Processes?. K4D Helpdesk Report 831. Brighton, UK: Institute of Development Studies. [Online]. Available:

https://opendocs.ids.ac.uk/opendocs/handle/20.500.12413/15402.

[3] W. L.Neuman, "Social research methods: qualitative and quantitative approaches", Pearson, 2014

[4] H. Jenssen and J. P. B. Unhjem, "An empirical analysis of housing allowance recipients 2010-2020 and a forecast of the near future" (Master's thesis, Handelshøyskolen BI), 2020.

[5] "Conclusions of The 6Th Meeting Of The Quadripartite Steering Committee: Solutions Strategy For Afghan Refugees To Support Voluntary Repatriation, Sustainable Reintegration And Assistance To Host Countries 2019", presented at UN High Commissioner for Refugees, Islamabad, 2019. Available:https://unhcrpk.org/afghanistan-iran-pakistan-and-unhcrmeet-to-discuss-implementation-of-the-solutions-strategy-for-afghanrefugees/.

[6] V. Ullom, "Voluntary repatriation of refugees and customary international law", Denv. J. Int'l L. \&Pol'y, 29, p.115, 2000.

[7] V. Hiegemann, "Repatriation of Afghan Refugees in Pakistan: Voluntary?", Oxford Monitor of Forced Migration, 4(1), pp.1-4, 2014.

[8] M. Qayyum, "Why Afghan refugee women in Pakistan fear repatriation?"AlJazeera,2018.Available:https://www.aljazeera.com/fe atures/2019/5/9/why-afghan-refugee-women-in-pakistan-fearrepatriation[Accessed 17 Oct.2020].

[9] "Afghanistan Multi-Year Protection and Solutions Strategy (20192021)”, presented at UN High Commissioner for Refugees, 2018.

[10] "World Health Organization Report 2017: Rights Trends in Afghanistan." Human Rights Watch, 2017. Available: https://www.hrw.org/world-report/2017/country-chapters/afghanistan [Accessed 28 Dec. 2019].

[11] L. Maizland, "U.S.-Taliban Peace Deal: What to Know," presented at the Council On Foreign Relations, March 2020.

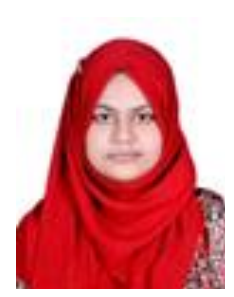

Sumaya Khan Auntu was born in Tangail, 11th of November, 1996. Currently, she is pursuing her Bachelor of Social Sciences (BSS) in International Relations at Bangladesh University of Professionals, Dhaka, Bangladesh. She had completed her internship from Family Planning Association of Bangladesh, Dhaka. Her preferable areas of interest are Crisis Management, Peace and Conflict Studies, International Development, UN Peacekeeping Operations, International Relations in Politica Thoughts, Migration Studies, and Public Policy. The work, she has represented here is related to crisis management.

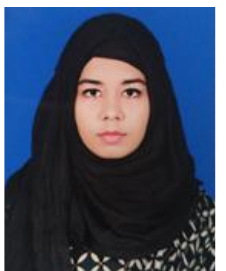

Afia Tasnim Promee was born in Chattogram, Bangladesh, on $14^{\text {th }}$ April 1999. She is currently pursuing her Bachelor of Social Sciences (BSS) (Honors) in international relations from Bangladesh University of Professionals. Her area of interest includes global affairs, peace and conflict studies, global migration and environmental studies. Her participation in this study indicates her interest to global migration and refugee crisis. 